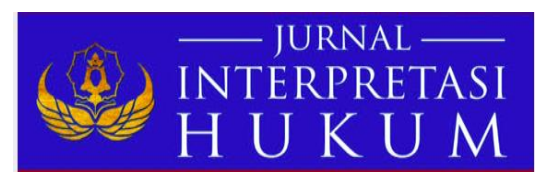

\title{
PERLINDUNGAN HUKUM BAGI KONSUMEN TERHADAP KERUGIAN DALAM LAYANAN PENGGUNAAN PAKET INTERNET PROVIDER
}

\author{
Nurin Fitriana Ulfa; I Nyoman Putu Budiartha; Desak Gde Dwi Arini \\ Fakultas Hukum Universitas Warmadewa, Denpasar - Bali, Indonesia
}

\begin{abstract}
Abstrak
Perlindungan hukum bagi konsumen adalah suatu proses perlindungan yang diberikan kepada konsumen dalam usahanya untuk mendapatkan barang dan/atau jasa yang diinginkan dan kemungkinan akan timbul suatu kerugian dalam menggunakannya, maka hukum berlaku untuk melindungan konsumen. Penelitian ini bertujuan untuk mengatahui perlindungan hukum bagi konsumen provider terhadap kerugian dalam penggunaan paket data internet yang telah habis batas penggunaannya tetapi tidak mendapatkan pemberitahuan dan pertanggung jawaban pihak provider terhadap kerugian konsumen pengguna paket data internet. Metode yang digunakan dalam penelitian ini adalah penelitian hukum empiris dengan menggunakan pendekatan perundang-undangan, konseptual dan sosiologis. Data primer dan sekunder merupakan data yang digunakan dalam penelitian ini. Kemudian penelitian ini dianalisis secara kualitatif. Berdasarkan analisis, hasil penelitian ini menunjukkan bahwa perlindungan hukum bagi konsumen terhadap kerugian dalam layanan penggunaan paket internet provider proses penyelesaian sengketa dengan pertanggungjawaban oleh pihak Telkomsel. Pertanggungjawaban sebagai upaya terhadap perlindungan konsumen dari pihak provider kepada konsumen yang berakibat dengan kerugian konsumen berupa pemotongan pulsa belum sepenuhnya terlaksanakan, karena tidak semua permasalahan provider akan diberikan ganti kerugian dalam bentuk apapun.
\end{abstract}

Kata Kunci: Kerugian Layanan Paket Internet; Konsumen; Perlindungan Hukum; Provider

\begin{abstract}
Legal protection for consumers is a process of protection provided to consumers in their efforts to obtain the desired goods and/or services and the possibility of a loss in using them, the law applies to protect consumers. This study aims to find out the legal protection for consumers of providers against losses in the use of internet data packages that have used up but have not received notification and responsibility of the provider for the loss of consumers of internet data package users. The method used in this study is empirical legal research using a statutory, conceptual and sociological approach. Primary and secondary data is data used in this study. Then this study was analyzed qualitatively. Based on the analysis, the results of this study indicate that the legal protection for consumers against losses in services using the internet provider package is the process of resolving disputes with accountability by Telkomsel. Liability as an effort to protect consumers from the provider to consumers that results in consumer losses in the form of credit cuts has not been fully implemented, because not all provider problems will be given compensation in any form.
\end{abstract}

Keywords: Losses Internet Package Services; Consumer; Legal Protection; Provider

\section{PENDAHULUAN}

Konsumen merupakan pembeli yang memakai barang/jasa yang terdapat dalam masyarakat untuk memenuhi kebutuhan diri sendiri, keluarga dan makhluk hidup lainnya. Perlindungan hukum bagi konsumen adalah suatu proses perlindungan yang diberikan untuk konsumen dalam usahanya guna mendapatkan barang/jasa yang diinginkan dan memungkinan akan timbulnya suatu kerugian dalam menggunakannya, maka hukum berlaku untuk melindungan konsumen. Kewenangan untuk memberikan perlindungan hukum kepada konsumen dapat diatur dalam Undang-Undang Nomor 8 Tahun 1999 yang berfungsi untuk melindungi dan dasar hukum dalam pengaturan perlindungan konsumen. Setiap 
konsumen juga memiliki hak atas kepastian hukum yang terdapat dalam sebuah perjanjian dengan para pelaku usaha, tak terkecuali dengan kerugian yang dialami konsumen dalam melakukan suatu perjanjian terhadap pelaku usaha. Dalam pasal 18 ayat (1) point b Undang-Undang Perlindungan Konsumen tentang ketentuan atau syarat dibuat terlebih dahulu oleh pelaku usaha yang menentukan bahwa pelaku usaha berhak untuk menolak pengembalian barang yang telah dibeli oleh konsumen.

Dari aturan tersebut menjelaskan bahwa tidak semua barang/jasa yang didapat oleh konsumen akan sesuai dengan perjanjian yang telah diperjanjikan oleh pelaku usaha. Kemajuan dibidang teknologi juga mendukung pergerakan transaksi barang/jasa sehingga dapat melampaui berbagai wilayah negara. Sehingga didukungnya teknologi tersebut, dapat memberikan keuntungan terhadap konsumen karena dapat membantu kebutuhannya tanpa harus mengunjungi pelaku usaha secara langsung dan memiliki berbagai ragam pilihan. Adapun kekurangan dari hal tersebut menjadikan posisi konsumen menjadi lemah dimata produsen, karena konsumen menjadi objek dalam keuntungan yang besar bagi produsen dengan memberikan promosi yang merugikan konsumen (Negoro, 2011:11).

Di era modern saat ini banyaknya sarana komunikasi yang digunakan oleh setiap orang bahkan seluruh dunia, sehingga membuat jumlah pengguna naik secara signifikan pertahun. Dengan bertambahnya pengguna yang sangat pesat dapat menuntut pihak provider agar bisa melayani pelanggan yang semakin lama semakin bertambah. Dengan meningkatnya pengguna di masyarakat, setiap provider harus memiliki jaringan yang bagus sehingga mampu meningkatkan komunikasi saat ini.

Penggunaan sarana komunikasi pada saat ini yang sangat diminati yaitu jaringan internet. Karena dapat menghemat biaya, internet juga dapat digunakan dalam konten multimedia. Dalam menggunakan suatu internet saat ini tidak dapat dilepas dari jaringan seluler dari berbagai provider. Maksudnya teknologi dan provider merupakan satu kesatuan yang tidak dapat dipisahkan. Di Indonesia terdapat sepuluh perusahaan dimana terbagi menjadi lima Provider berbasis Global System for Mobile Communication (GSM) dan lima Provider berbasis Code Division Multiple Access (CDMA). Dalam bisnis seluler GSM terdapat tiga ISP yang memiliki izin secara nasional yaitu Telkomsel, Indosat, dan XL Axiata (Unknown, 2016:23, 10, 2019).

Jaringan GSM merupakan jaringan seluler yang digunakan oleh sebagian besar stasiun siaran yang terhubung langsung pada sinyal dari orbit. Sedangkan CDMA yaitu sistem jaringan pada seluler yang dipelajari lebih luas dan disebarkan oleh Negara Amerika dan Jepang. CDMA yaitu suatu jaringan yang terhubung dengan jaringan yang lain yang berjauhan tetapi tidak saling mengganggu, yang berdasarkan teknik komunikasi spektrum yang memiliki kemiripan dengan GSM. Sedangkan kelemahannya tidak memilki ketersediaan berbagai handset atau perangkat komunikasi mobile di CDMA seperti pada GSM (Wikipedia, 2015:23, 10, 2019).

Perkembangan internet yang cukup besar membawa dampak bagi pihak- pihak yang memanfaatkan internet, seperti bertukar data, transaksi online, promosidan lain sebagainya. Sehingga membutuhkan keamanan dalam berinternet untuk mengurangi kejahatan yang terdapat dalam internet tersebut, dengan adanya kejahatan membuat para pengguna merasa kurang nyaman dan merasa diincar oleh para penjahat setiap kali mereka melakukan transaksi di internet. Perkembangan bisnis telekomunikasi di Indonesia sangat pesat, terbukti dengan banyaknya provider yang bersaing di Indonesia. Setiap provider membuat ide atau gagasan untuk meningkatkan penjualan produknya, salah satunya dengan mengeluarkan berbagai promosi baik melalui iklan media cetak ataupun media elektronik.

Hal tersebut tak sesuai dengan berita yang beredar tentang berbagai macam promo yang dikeluarkan oleh pihak provider seluler. Dalam contoh kasus yang merugikan masyarakat yaitu penggunaan paket data internet yang telah habis batas penggunaanya tetapi masa berlakunya masih panjang dan konsumen tidak mendapatkan informasi berupa sms (short message service) yang mengakibatkan penyedotan pulsa secara tiba-tiba dengan jumlah yang sangat banyak.

Beberapa penelitian terkait serupa tentang pelindungan hukum bagi konsumen telah dikaji sebelumnya oleh beberapa peneliti seperti Helmi (2011), Fadhli \& Bahri (2018). Sari \& Nugroho (2019) juga mengkaji penelitian serupa tentang perlindungan konsumen pengguna layanan internet bolt dan bolt home yang dicabut izinnya oleh Kominfo dan tanggungjawab dari pelaku bisnis untuk konsumen bolt dan pelanggan layanan internet bolt home. Hasil penelitian Sari \& Nugroho (2019) ini menunjukkan bahwa 
konsumen bolt dan bolt home hanya mendapatkan perlindungan preventif dengan menonaktifkan layanan pembayaran top-up untuk menghindari kerugian yang lebih besar bagi konsumen, sementara perlindungan represif tidak ditemukan dalam kasus ini. Bentuk tanggung jawab PT. Internux kepada konsumen berdasarkan ketentuan Pasal 19 ayat (1) dan (2) harus memberikan kompensasi yang setara dengan harga paket kuota sesuai dengan perjanjian awal yang disepakati dengan mekanisme pengembalian uang dan memberikan layanan penawaran pengalihan kepada penyedia lain. Jumaianti (2020) juga mengkaji penelitian serupa tentang bagaimana pelaksanaan perjanjian antara PT. Telkom dengan pelanggan IndiHome di area Telkom Malang dan Bagaimana perlindungan hukum konsumen apabila terjadi gangguan jaringan internet di area Telkom Malang. Hasil penelitian Jumaianti (2020) ini menunjukkan bahwa PT. Telkom sebagai penyedia layanan IndiHome memiliki kontrak berlangganan layanan IndiHome dengan menandatangani perjanjian kontrak saat melakukan registrasi maka konsumen telah menyetujui dan memahami hak dan kewajibannya. Konsumen yang meneyetujui dan menandatangani kontrak mengenai segala sesuatu resiko yang akan ditanggung dan tidak memaksa para konsumen untuk menerima perjanjian tersebut jika dirasa kurang tepat.

Dari latar belakang dan penelitian terdahulu di atas, penelitian sekarang ini bertujuan untuk mengatahui perlindungan hukum bagi konsumen provider terhadap kerugian dalam penggunaan paket data internet yang telah habis batas penggunaannya tetapi tidak mendapatkan pemberitahuan dan pertanggung jawaban pihak provider terhadap kerugian konsumen pengguna paket data internet.

\section{METODE PENELITIAN}

Penelitian ini adalah penelitian hukum empiris dengan menggunakan pendekatan perundang-undangan, konseptual dan sosiologis. Data primer dan sekunder merupakan data yang digunakan dalam penelitian ini. Data primer yaitu data yang berupa sejumlah keterangan atau fakta yang dapat di wawancara secara langsung dari lokasi penelitian di Jalan Pratama, Desa Tanjung Benoa, Kelurahan Kuta Selatan, Kabupaten Badung. Wawancara di beberapa counter hanphone, dan gerai Provider (Telkomsel) yang terletak di kawasan Nusa Dua. Data sekunder yaitu data yang bersumber dari bahan hukum primer, bahan hukum sekunder, kepustakaan, media internet, dan literatur-literatur yang berkaitan. Lokasi penelitian ini dilakukan di Jalan Pratama, Desa Tanjung Benoa, Kelurahan Kuta Selatan, Kabupaten Badung. Teknik pengumpulan data yang digunakan dalam penelitian ini adalah dengan cara wawancara, observasi atau pengamatan dan kepustakaan. Kemudian penelitian ini dianalisis secara kualitatif.

\section{HASIL PENELITIAN DAN PEMBAHASAN \\ Perlindungan Hukum Bagi Konsumen Terhadap Kerugian Dalam Penggunaan Paket Data Internet Provider}

Menurut Ahmadi Miru dan Sutarman Yodo yang terdapat dalam buku Hukum Perlindungan Konsumen pada tahun 2014, yaitu:

Pesan pemberitahuan terkait penggunaan paket internet bagi konsumen sangatlah penting. Menurut Ahmadi Miru informasi yang rinci sangat dibutuhkan oleh konsumen, agar mendapatkan bayangan dengan jelas dalam sebuah produk, karena dengan adanya informasi yang jelas konsumen bisa memilih produk yang diminati atau sesuai dengan kebutuhan sehingga tidak adanya kerugian akibat dari kesalahan dalam menggunakan produk (Miru \& Yodo, 2004:41).

Namun informasi berupa pesan singkat belum didapatkan oleh beberapa konsumen sesuai yang diharapkan. Kerugian biasaya diawali dengan paket data internet yang sudah habis masa kuotanya tetapi konsumen tidak mendapatkan sms pemberitahuan mengenai sisa kuota internet dan juga status paket internet yang sudah habis tersebut. Sehingga mengakibatkan pulsa reguler milik konsumen terpakai sebagai biaya penggunaan internet tanpa diketahui oleh konsumen. Dimana biaya penggunaan internet melalui pulsa reguler yang ada menjadi tariff yang jauh lebih mahal dari harga paket. Pesan pemberitahuan berupa sms dari provider selaku pelaku usaha kepada konsumen atas penggunaan paket internet, adalah kewajiban bagi pelaku usaha yang harus dilaksanakan.

Jika ternyata masih terdapat beberapa konsumen pengguna paket internet yang tidak mendapatkan sms pemberitahuan, tentu hal tersebut merupakanpelanggaran terhadap hak konsumen seperti yang 
tercantum dalam peraturan tersebut. Konsumen juga memiliki kewajiban yang harus dipenuhi dan hak yang didapatkan. Kewajiban konsumen terhadap penggunaan paket internet yaitu melakukan pembayaran layanan internet sebelum menggunakannya. Sedangkan hak yang didapat konsumen yaitu konsumen akan mendapatkan apa yang telah mereka bayar, konsumen dapat selalu melakukan complain atas keluhan yang mereka rasakan.

Pihak Telkomsel memberitahukan bahwa sebelumnya memang selalu terdapat banyak adanya keluhan dari pelanggan mengenai sms yang tidak didapatkan, serta pulsa yang tidak sedikit terpotong karena biaya akses internet. Dari pihak Telkomsel juga menjelaskan mengenai sms yang tidak didapatkan oleh para konsumen karenak adanya kealpaan dari sistem pada jaringan operator Telkomsel, maka setiap ada keluhan dari pelanggan, maka pihak Telkomsel akan memberikan saran untuk melakukan pengecekan ulang pada paket internet mereka. Pesan pemberitahuan sms bertujuan untuk memperingati para pengguna paket internet, bahwa paket internet yang digunakan oleh konsumen akan segera habis kuotanya atau akan segera habis masa berlakunya.

Berikut merupakan sms pemberitahuan dari operator Telkomsel: (diakses pada 3 Februari 2020).

20-01-2020 23:11:36. Plg Yth, sisa kuota Flash Anda 90.00MB. Download MyTelkomsel apps di http://tsel.me/tsel utk cek kuota\&beli paket Flash atau hub *363\#.

Tetapi pada kenyataannya ada beberapa konsumen yang masih mengeluh belum mendapatkan sms pemberitahuan tersebut ketika menggunakan paket data internet. Padahal sms pemberitahuan adalah peringatan yang harus didapat oleh konsumen untuk dapat melindungi konsumen dari kerugian terhadap pemotongan pulsa saat data seluler menyala. Pada saat kuota internet milik konsumen akan habis, konsumen terlebih dahulu harus mendapatkan pemberitahuan agar konsumen lebih berhati-hati dalam mengakes internet. Agar konsumen tidak mengalami kerugian berupa pemotongan pulsa reguler. Hal tersebut merupakan sebuah bentuk upaya perlindungan hukum bagi konsumen yang bersifat untuk mencegah terjadinya pelanggaran hak-hak konsumen yang menimbulkan pelanggaran.

Selain peringatan, intruksi bertujuan untuk menjamin efisensi penggunaan produk juga sangat penting untuk mencegah terjadinya kerugian konsumen. Dengan mencantumkan informasi tersebut dapat memberikan kewajiban bagi produsen dianggap tidak cacat (Miru \& Yodo, 2004:60). Untuk dapat menjamin suatu barang jasa dalam pemakaian konsumen, maka pelaku usaha memberikan kualitas yang baik untuk memberikan kenyamanan dan kepercayaan bagi konsumen pengguna paket internet (Barkatullah, 2010:34).

Dalam penyelesaian sengketa konsumen yang dilakukan diluar pengadilan untuk mencapai kesepakatan dalam bentuk besarnya ganti rugi yang dialami oleh konsumen atas produk yang telah diproduksi oleh pelaku usaha. Untuk mencegah terjadinya hal tersebut, maka perlunya lembaga yang menyelesaikan sengketa konsumen diluar pengadilan yaitu Badan Penyelesaian Sengketa Konsumen (BPSK) yang mana bertugas sebagai penanganan dan penyelesaian sengketa atara pelaku usaha dan konsumen diluar pengadilan. Dalam penyelesaian ini konsumen memiliki kewenangan melakukan penanganan dengan cara mediasi atau arbitrase atau konsiliasi.

\section{Pertanggung Jawaban Pihak Provider Terhadap Kerugian Konsumen Pengguna Paket Data Internet}

Teknologi internet merupakan paket data dengan jaringan yang tersebar perkembangan penggunaan internet sebagai sarana komunikasi global, membuat dunia semakin tidak memiliki batas. Sehingga dengan adanya internet tentu sejalan dengan era globalisasi. Seiring dengan kemajuan teknologi, saat ini jaringan informasi yang didapat oleh konsumen dapat saling terhubung dengan jaringan lain diseluruh dunia melalui jaringan internet.

Segala sesuatu yang dikirim melalui internet dipecah-pecah menjadi data yang berukuran kecilkecil untuk mempermudah pengiriman paket. Data-data tersebut diteruskan pada tempat tujuan melalui jalur-jalur komunikasi data yang terhubung ke sebuah alat yang dinamakan router, yaitu perangkat jaringan sebagai analisa lalu dikirimkan paket data dari satu jaringan ke jaringan yang lainnya.

Dalam mengakses informasi melalui intenet dibutuhkan koneksi yang dapat saling terhubung, juga diperlukan alat seperti handphone, komputer, laptop dan sebagainya, menggunakan alat komunikasi tersebut juga dibutuhkan jaringan yang bernama jaringan internte provider. Yang mana internet provider 
merupakan suatu bentuk usaha dari beberapa perusahaan. Setiap provider memiliki daya tarik tersendiri untuk memikat para konsumennya, begitu pula dengan Telkomsel. Penawaran paket data internet dilakukan dengan berbagai cara, baik melalui iklan media cetak, maupun media digital. Berikut ini adalah konsep paket data internet yang dimiliki oleh Telkomsel (Nurvitasari, 2017).

Kuota Flash Telkomsel, Kuota Lokal Telkomsel, Kuota Midnights/Mds (Midnights Data Servivce) Telkomsel, Kuota 4G Telkomsel, Kuota VideoMax Telkomsel, Kuota Chatting Telkomsel, Kuota Facebook Telkomsel, Kuota Youtube Telkomsel, Kuota 4G-Midnights Telkomsel, Kuota Maxtream Telkomsel, Kuota OMG Telkomsel, dan Kuota Ilmu Pedia Telkomsel.

Menurut penulis, tanggung jawab atas kerugian terhadap perbuaan melanggar hukum merupakan tanggung jawab yang harus dipikul oleh provider. Pertanggung jawaban yang didapat dari pihak provider yaitu penggantian kartu dengan melaluiproses pengecekan kartu konsumen terlebih dahulu selama tiga hari kerja hingga tujuh hari kerja. Apabila terdapat kesalahan dalam operator, maka konsumen mendapatkan ganti kerugian berupa penggantian kartu milik konsumen. Dan apabila kesalahan ini terjadi karena kelalaian konsumen, maka pihak provider tidak memberikan pertanggung jawaban berupa apapun.

Apabila melihat dari perbuatan melanggar hukum yang terdapat dalam Pasal 1365 KUH Perdata, yang mana menjelaskan bahwa setiap perbuatan yang melanggar hukum maka akan mendapatkan kerugian terhadap orang lain, sehingga orang yang melanggar hukum tersebut untuk mengganti kerugian yang dialami oleh orang lain.

Dari hasil wawancara dengan customer service Kantor Grapari Telkomsel Nusa Dua yang diwakili oleh Ibu Wiwik pada 7 Maret 2020 pihak Telkomsel tidak akan memberikan sebuah ganti kerugian dalam bentuk apapun kepada konsumen terkait kasus pemotongan pulsa reguler secara tiba-tiba tanpa diketahui oleh konsumen saat menggunakan internet. Menurutnya kerugian yang dialami konsumen merupakan sebuah ketentuan dari penggunaan tarif yang ditetapkan pada produk internet milik Telkomsel bagi pemilik kartu prabayar. Jadi menurut pihak Telkomsel pemotongan pulsa konsumen secara tiba-tiba itu merupakan ketentuan yang sesuai, dari konsumenlah yang harus menghindarkan diri dari penggunaan yang menimbulkan kerugian tersebut.

Walaupun pihak Telkomsel tidak memberikan ganti rugi mengenai kasus tersebut, tetapi pihaknya akan beritikad baik untuk memenuhi kewajibannya dengan cara memberikan ganti kerugian untuk permasalahan paket internet lainnya, sebelum digantikan kerugian maka akan dilakukan proses pengecekan terhadap keluhan konsumen tersebut.

Dari analisis kasus diatas, penulis kurang setuju dengan tanggung jawab yang diberikan oleh pihak Telkomsel karena pihak Telkomsel tidak memberikan pertanggung jawaban apapun atas kerugian yang dialami konsumen, sehingga membuat konsumen tidak merasakan kepuasan dan kenyamanan dalam menggunakan produk yang disediakan oleh Telkomsel. Meskipun konsumen telah mendapatkan ganti kerugian berupapenggantian kartu akan tetapi konsumen merasa kurang puas dikarenakan tidak mendaatkan penjelasan secara detail mengenai permasalahan yang dialaminya, serta tidak mendapatkan penjelasan cara menanggulangi apabila terjadi permasalahan yang sama.

\section{SIMPULAN DAN SARAN}

\section{Simpulan}

Berdasarkan hasil analisis dan pembahasan yang dilakukan, dapat ditarik simpulan sebagai berikut: 1) Perlindungan hukum bagi konsumen provider terhadap kerugian dalam penggunaan paket data internet yang telah habis batas penggunaanya tetapi tidak mendapatkan pemberitahuan dan pihak dari Grapari merasa bahwa telah memberikan informasi terhadap konsumen, dari hasil wawancara dengan pihak customer service dari Kantor Grapari Telkomsel yang menjelaskan bahwa dengan adanya keluhan yang dirasakan oleh beberapa konsumen, mengatakan pihaknya telah memberikan informasi dengan benar yaitu dengan mengirimkan sms pemberitahuan penggunaan paket data internet pada konsumen 1 hari sebelum paket data internet milik tersebut akan berakhir ataupun batas kuota internet konsumen memasuki tahap limit. 2) Pertanggungjawaban sebagai upaya terhadap perlindungan konsumen dari pihak provider kepada konsumen yang berakibat dengan kerugian konsumen berupa pemotongan pulsa belum sepenuhnya terlaksanakan, karena tidak semua permasalahan provider akan diberikan ganti kerugian 
dalam bentuk apapun. Tetapi pihak provider tidak akan melepaskan tanggung jawab begitu saja terhadap kerugian konsumennya, bentuk tanggung jawab tersebut dapat berupa penggantian pulsa dan pembaharuan kartu seluler dengan catatan kartu konsumen dicek oleh operator terlebih dahulu.

\section{Saran}

Berdasarkan simpulan di atas, maka dapat diberikan saran-saran yaitu: 1) Pihak operator sebagai pelaku usaha memiliki kewajiban memberikan pelayanan yang utuh kepada konsumen, terutama untuk memenuhi hak- hak dari konsumen. Khususnya hak mengenai informasi yang benar serta jelas terhadap penggunaan paket data internet sehingga tidak menimbulkan kerugian bagi konsumen atas pemotongan pulsa regulernya, karena kurang mendapatkan pengarahan informasi dan tidak mendapatkan pemahaman dari pihak operator provider. 2) Konsumen sebagai pengguna paket data internet harus lebih cerdas dalam memilih paket data internet yang dipromosikan. Konsumen harus lebih cermat dalam memiih dan menggunakan paket data internet, tidak hanya tergiur oleh promosi yang diberikan oleh pihak provider. Konsumen juga sudah harus sadar dan mengerti mengenai segala haknya, dan ketika konsumen khususnya konsumen provider merasa haknya ada yang terlanggar, maka sebaiknya konsumen mengajukan komplain kepada pihak yang melakukan pelanggaran guna memperjuangkan haknya, yaitu kepada pihak provider atau di kantor pelayanan dari masing-masing operator seluler.

\section{DAFTAR PUSTAKA}

Barkatullah, A. H. (2010). Hak-hak Konsumen. Bandung: Nusa Media.

Fadhli, Z., \& Bahri, S. (2018). Perlindungan Hukum Terhadap Pelanggan Jasa Telekomunikasi Dalam Registrasi Kartu Seluler Prabayar Melalui Gerai (Suatu Penelitian Di Kota Banda Aceh). Jurnal Ilmiah Mahasiswa Bidang Hukum Keperdataan, 2(4), 743-751.

Helmi, H. R. (2011). Perlindungan Hukum Bagi Pengguna Jasa Operator Seluler Atas Adanya Short Message Service (SMS) Spam. Yuridika, 26(3).

Jumaianti. (2020). Perlindungan Hukum Terhadap Konsumen Karena Adanya Gangguan Jaringan Internet (Studi di PT. Telkom Area Malang). DINAMIKA: Jurnal Ilmiah Ilmu Hukum, 26(1), 64-75.

Miru, A., \& Yodo, S. (2004). Hukum Perlindungan Konsumen. Jakarta: PT. Grafindo Persada.

Negoro, S. A. (2011). Proses Penyelesaian Sengketa Ditinjau Dari Hukum Acara Serta Kendala Implementasinya. Jakarta: Kencana.

Nurvitasari, E. (2017). Macam/Jenis Kuota Data Internet Telkomsel (Simpati, Kartu As, dan Loop). Retrieved 17 February 2020

Sari, F. I., \& Nugroho, S. A. (2019). Perlindungan Konsumen Pengguna Layanan Internet Bolt dan Bolt Home yang Dicabut Izinnya oleh Kementerian Komunikasi dan Informatika Tahun 2018. Jurnal Hukum Adigama, 2(1), 51. 